\title{
ABSENCE OF DOPPLER SIGNAL IN TRANSCRANIAL COLOR-CODED ULTRASONOGRAPHY MAY BE CONFIRMATORY FOR BRAIN DEATH: A CASE REPORT
}

\author{
Mehmet Akif TOPÇUOĞLU, Ethem Murat ARSAVA \\ Hacettepe University Faculty of Medicine Department of Neurology, Ankara, TURKEY
}

\begin{abstract}
Transcranial Doppler ultrasonography (TCD) is a valuable tool for demonstrating cerebral circulatory arrest (CCA) in the setting of brain death. Complete reversal of diastolic flow (to-and-fro flow) and systolic spikes in bilateral terminal internal carotid arteries and vertebrobasilar circulation are considered as specific sonogram configurations supporting the diagnosis of CCA. Because of the possibility of sonic bone window impermeability, absence of any waveform in TCD is not confirmatory for CCA unless there is documentation of disappearance of a previously well detected signal by the same recording settings. Transcranial color-coded sonography (TCCS) with B-mode imaging can reliably detect adequacy of bone windows with clarity contralateral skull and ipsilateral planum temporale visualization. Therefore, absence of detectable intracranial Doppler signal along with available ultrasound window in TCCS can confirm clinical diagnosis of brain death. We herein discuss this entity from the frame of a representative case.
\end{abstract}

Key Words: Brain death, Doppler, temporal bone, ultrasound penetrance.

\section{TRANSKRANIAL RENKLİ DOPPLER ULTRASONOGRAFIDE SINYAL TESPIT EDILEMEMESİ BEYIN ÖLÜMÜ KLİNIK TANISI DOĞRULAYICI BİR BULGU OLABİLİ: OLGU SUNUMU}

\section{ÖZET}

Transkranial Doppler ultrasonografi beyin ölümünde serebral sirkülatuar arrestin dökümente edilmesinde değerli bir yöntemdir. Dopplerde her iki internal karotid arter/orta serebral arter kompleksi ve baziller arterde ya da her iki intrakranial vertebral arterde akımın diastolde tam olarak geri döndüğünün ("to-and-fro" paterni) veya sistolik dikenlerin tespit edilmesi serebral sirkulatuar arrest tanısını detekler. Eğer Dopplerde herhangi bir vascular Doppler sinyali elde edilemezse bunun sonik pencere yetersizliğinden mi yoksa gerçekten sinyal olmamasından mı kaynaklandığı ayırt edilemez. Bazı otörlere göre daha önceden aynı pencereden alınan bir sinyalin daha sonra kaybolması değerlidir ama bu klinikte emin olma bağlamında problematiktir. Diğer taraftan transkranial B-mod ultrasonografi ile ultrasonik kemik pencerenin yeterliliği tespit edilebilir. İşte, kemik pencerenin yeterli olduğu ama hiç Doppler sinyali kaydedilemeyen böyle bir hastada beyin ölümü tanısı doğrulanmıș olur mu sorusu bu makalede örnek bir olgu temelinde tartışılmıștır.

Anahtar Sözcükler: Beyin ölümü, Doppler, Temporal kemik, ultrasonik penetrans.

\section{INTRODUCTION}

Utility of transcranial Doppler ultrasonography (TCD) in confirmation of brain death is well established. The reported sensitivity of TCD for diagnosing brain death is about $90 \%$ at average, ranging from $53.5 \%$ to $100 \%$ (1-5). Its specificity is much higher and actually is very close to $100 \%$ (99.6\% on average) (3-6). False-positive diagnosis of brain death by TCD was reported in $0.46 \%$ of cases published in the literatüre; (7-11) however, the significance of this finding is questionable because brain death developed in all of these cases after a short duration following the Doppler examination $(7,12)$.

TCD diagnosis of brain death requires

\footnotetext{
Corresponding author: Prof. Mehmet Akif Topcuoğlu, MD. Hacettepe University Faculty of Medicine Department of Neurology, Ankara, Turkey. Phone: +903123051806_ E-mail: matopcuglu@yahoo.com Received: 04.08.2014 Accepted: 10.09.2014

This article should be cited as following: Topcuoglu M. A, Arsava E. M. Absence of Doppler signal in transcranial color-coded ultrasonography may be confirmatory for brain death: A case report. Turkish Journal of Cerebrovascular Diseases 2015; 21 (2): 133-137. doi:10.5505/tbdhd.2015.85856.
} 
demonstration of cerebral circulatory arrest (CCA) by recording specific sonogram configurations in terminal, or intra-cranial, internal carotid arteries (ICA) bilaterally and also in the basilar artery or in both intracranial vertebral arteries. The CCA specific sonogram patterns are complete reversal of diastolic flow (reverberating or to-and-fro flow) and systolic spikes, indicating absence of any antegrade flow providing a meaningful degree of cerebral perfusion $(9,12-14)$. Unless disappearance of a previously well detected signal is clearly established, absence of any TCD waveform is not considered as diagnostic for CCA because of the possibility for a false positive result due to impermeability of sonic bone windows, which can be present in up to $40 \%$ (in average: $7.6 \%)$ of these patients $(4,12,15,16)$. In such cases, submandibular insonation of cervical ICAs, transorbital insonation of carotid siphons, and though arguable, contrast-enhanced transcranial color-coded sonography (TCCS) can be used as alternatives for neurosonological confirmation of brain death $(5,12,15,17,18)$. TCCS, when compared to TCD, has the advantage of visualizing cerebral tissue and therefore can provide valuable information on the adequacy of sonic bone Windows $(19,20)$. The case presented herein led us to suggest that TCSS demonstration of absence of any intracranial Doppler signal along with apparently adequate sonic bone windows can be used as a confirmatory tool in diagnosis of brain death.

\section{CASE}

A poor 20-year-old gentleman developed hemorrhagic type posterior leukoencephalopathy (PRES) in the setting of thrombotic thrombocytopenic purpura and acute rejection of renal transplantation. The clinical course was complicated by brachial artery thrombosis, necessitating forearm amputation, severe pneumonia, sepsis and secondary acute respiratory distress syndrome. He suffered from two cardiac arrests, but was resuscitated successfully. Following cardiac arrests, he was found have deep coma and absent brain stem reflexes. Because apnea test could not be completed due to occurrence of significant desaturation and hypotension, a confirmatory test was ordered to establish brain death diagnosis. TCCS failed to record any Doppler signal despite modification of ultrasound settings suitably for low flow status. However, brain parenchymal structures and contralateral skull were unequivocally identifiable in this TCCS study (Figure 1).

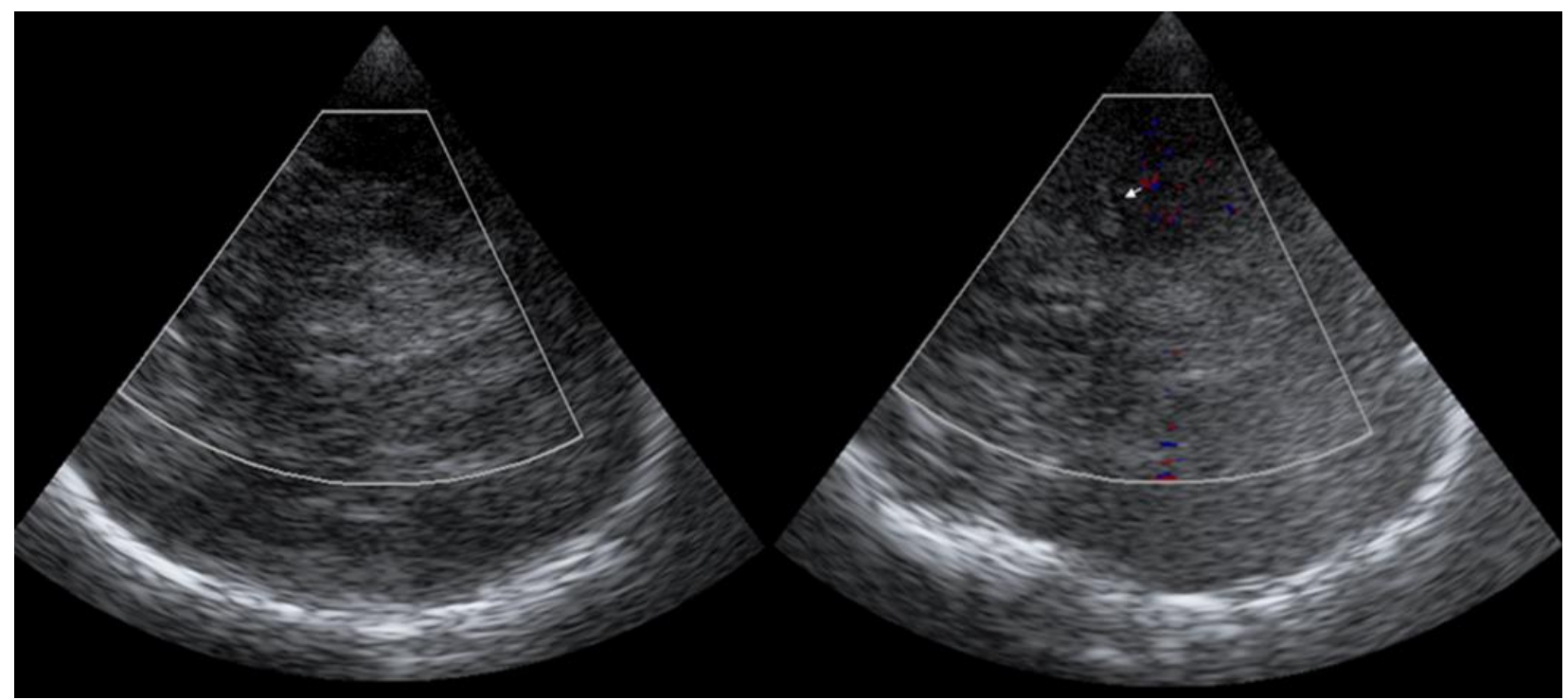

Figure 1. Transcranial color-coded ultrasonography shows absence of flow signal in any intracranial artery. Hyperechogenicity of the middle cerebral artery (arrow) is discernible. (Siemens Acuson X150®, pulse repetition frequency: $488 \mathrm{~Hz}$, persistence: 3; priority.4; gain $80 \mathrm{~dB}$; dynamic range: 50 ; gate: $10-\mathrm{mm}$ ). 
A computerized tomography angiography was then performed at the discretion of treating intensivists, and showed extensive brain edema
(Figure 2) along with absence of intracranial arterial and venous flow compatible with brain death (Figure 3).

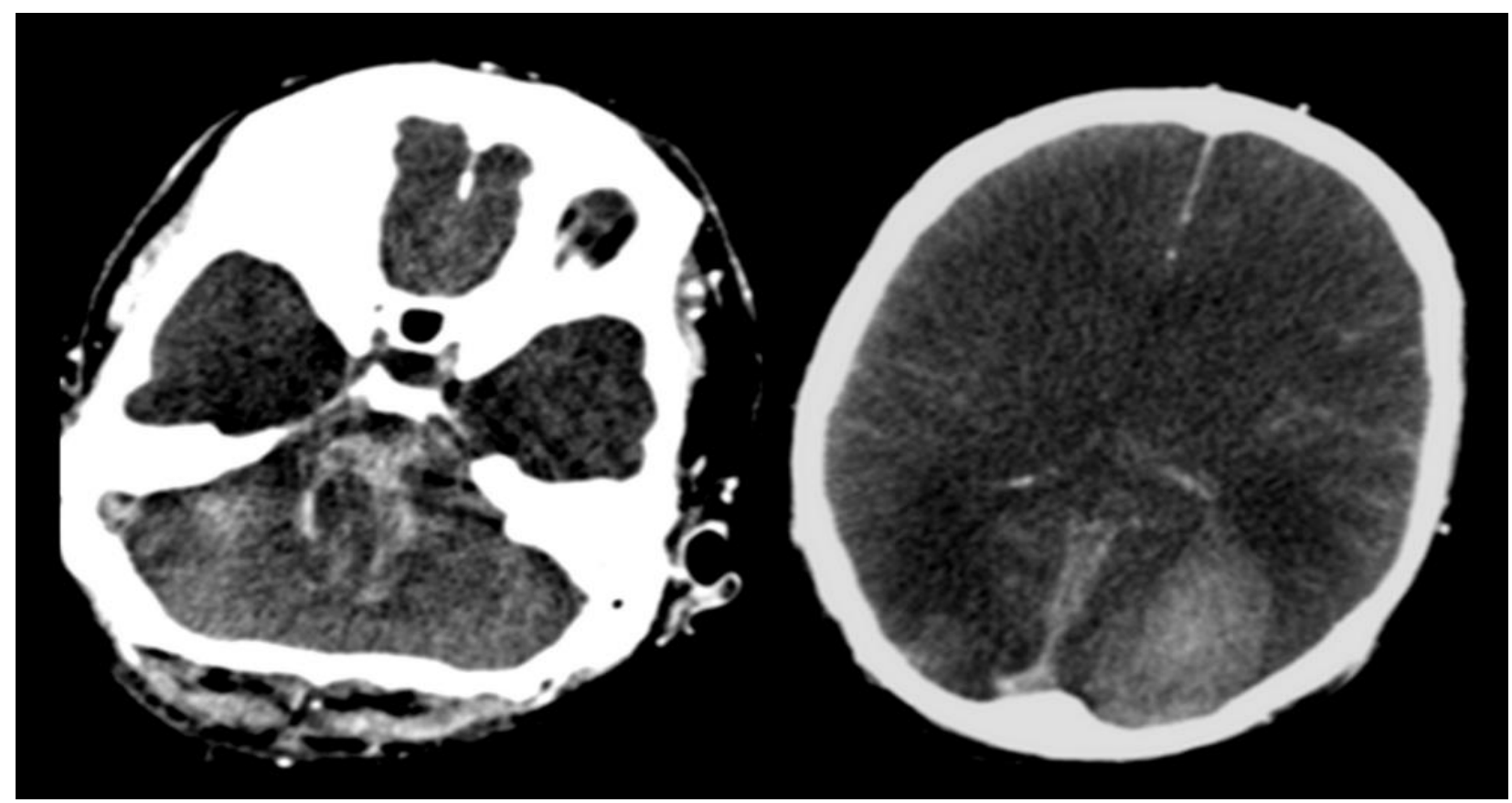

Figure 2. Brain CT shows massive edema along with Duret's type hemorrhage in the pontomedullary junction and subacute PRES-related hemorrhage in the left occipital lobe.

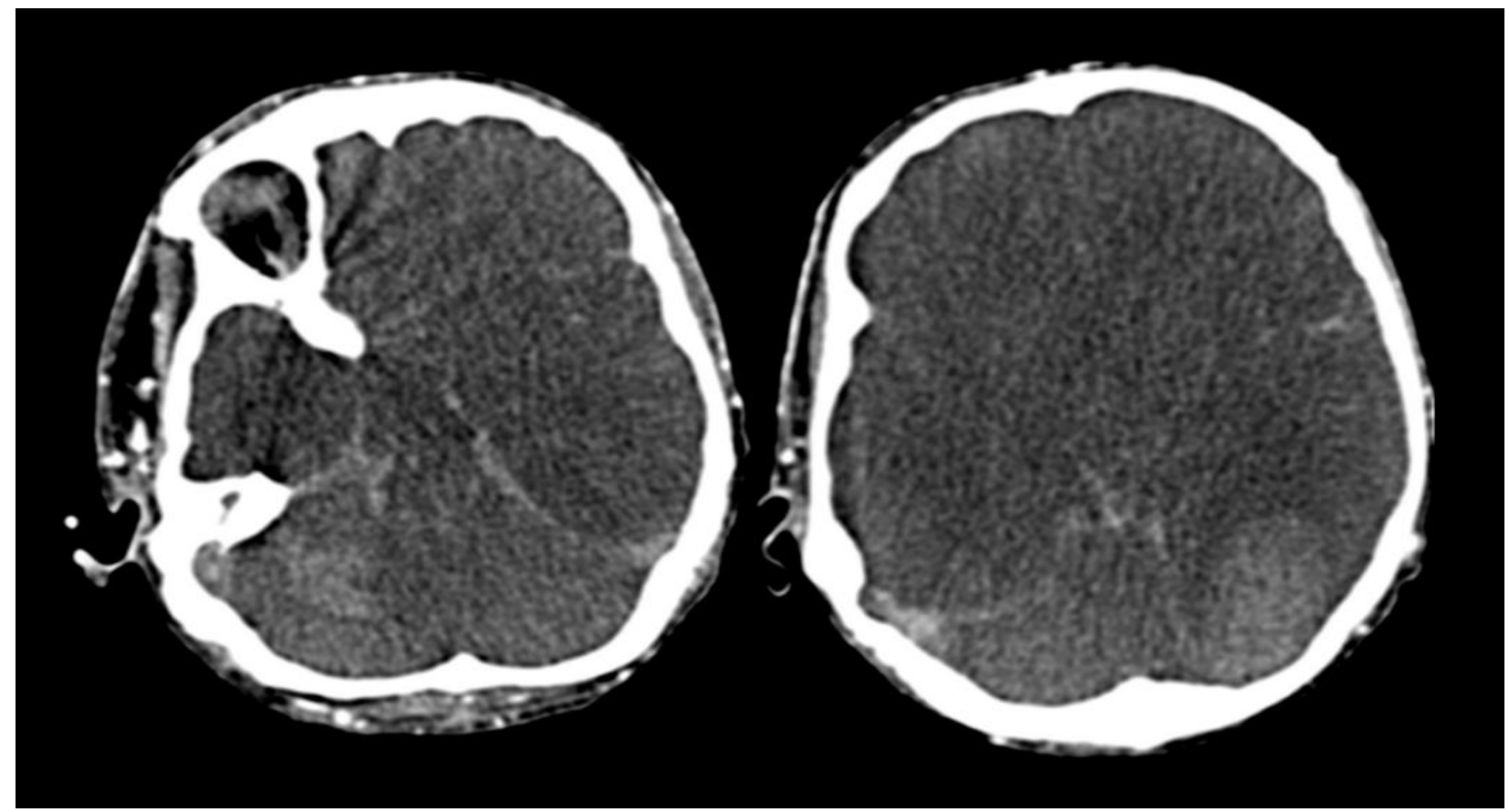

Figure 3. CT angiography shows no flow in intracranial arteries. A prominent extracranial vascular enhancement along with tentorial and meningeal hyperdensity (pseudo-subarachnoid hemorrhage appearance) are evident in these images. The blood pressure and oxygen saturation were maintained within normal levels (systolic blood pressure $>100 \mathrm{mmHg}$ and oxygen saturation $>96 \%$ ) during both TCCS and CT examinations. 


\section{DISCUSSION}

Experience with TCCS, albeit substantially lower than those with TCD, shows comparable sensitivity and specificity rates in terms of brain death confirmation $(21,22)$. The availability of acoustic window within the temporal bone does not significantly differ between TCD and TCCS (20). However the detection of window quality is easier and more rapid with TCCS through depiction of the main parenchymal and ventricular structures $(23,24)$. Furthermore, the temporal sonic window can be considered as sufficient when contralateral skull and ipsilateral lesser sphenoid wing are insonated as a thick and continuous hyperechogenic structure (24) as seen in the case presented herein. The other advantages of TCCS over TCD include, but are not limited to, easier vessel localization and discrimination, Doppler angle correction, and direct imaging of cerebral parenchyma for other pathologies (25). The presented case highlights an additional aspect of TCCS in brain death diagnosis, the verification of sufficiency of acoustic bone windows in the setting of absent intracranial Doppler signals. It is important to note that point-of-care ultrasonography devices routinely equipped with phased-array 2- to 3-MHz sector transducers and proper software that enable performing TCCS but not TCD, are becoming increasingly available in ICU environments. Therefore, familiarity of ICU physicians to this additional potential for TCCS in brain death confirmation is important. Properlyorganized studies are now required to test the sensitivity and specificity of our observation in confirming brain death diagnosis.

\section{REFERENCES}

1. Topcuoglu M, Arsava EM. Kafa içi basınç artışı nörosonolojisi. Turk Beyin Damar Hastaliklari Dergisi 2011;17:77.

2. Unal A, Dora B. Beyin ölümü tanısında destekleyici bir test olarak transkranial Doppler ultrasonografisi. Turk Beyin Damar Hastaliklari Dergisi 2012;18:49.

3. Monteiro LM, Bollen CW, van Huffelen AC, et al. Transcranial Doppler ultrasonography to confirm brain death: a meta-analysis. Intensive care medicine 2006;32:1937.

4. de Freitas GR, Andre C. Sensitivity of transcranial Doppler for confirming brain death: a prospective study of 270 cases. Acta neurologica Scandinavica 2006;113:426.

5. Conti A, Iacopino DG, Spada A, et al. Transcranial Doppler ultrasonography in the assessment of cerebral circulation arrest: improving sensitivity by transcervical and transorbital carotid insonation and serial examinations. Neurocritical care 2009;10:326.

6. Ducrocq X, Braun M, Debouverie M, et al. Brain death and transcranial Doppler: experience in 130 cases of brain dead patients. Journal of the neurological sciences 1998;160:41.

7. Dosemeci L, Dora B, Yilmaz M, et al. Utility of transcranial doppler ultrasonography for confirmatory diagnosis of brain death: two sides of the coin. Transplantation 2004;77:71.

8. Hadani M, Bruk B, Ram Z, et al. Application of transcranial doppler ultrasonography for the diagnosis of brain death. Intensive care medicine 1999;25:822.

9. Hassler W, Steinmetz H, Pirschel J. Transcranial Doppler study of intracranial circulatory arrest. Journal of neurosurgery 1989;71:195.

10. Newell DW, Grady MS, Sirotta P, et al. Evaluation of brain death using transcranial Doppler. Neurosurgery 1989;24:509.

11. Van Velthoven V, Calliauw L. Diagnosis of brain death. Transcranial Doppler sonography as an additional method. Acta neurochirurgica 1988;95:57.

12. Ducrocq X, Hassler W, Moritake K, et al. Consensus opinion on diagnosis of cerebral circulatory arrest using Dopplersonography: Task Force Group on cerebral death of the Neurosonology Research Group of the World Federation of Neurology. Journal of the neurological sciences 1998;159:145.

13. Lange MC, Zetola VH, Miranda-Alves M, et al. Brazilian guidelines for the application of transcranial ultrasound as a diagnostic test for the confirmation of brain death. Arquivos de neuro-psiquiatria 2012;70:373.

14. Topcuoglu MA, Arsava EM. How Doppler effect occurs in absence of intracranial blood flow in brain death? Medical hypotheses 2013;80:103.

15. Dominguez-Roldan JM, Jimenez-Gonzalez PI, Garcia-Alfaro $C$, et al. Diagnosis of brain death by transcranial Doppler sonography: solutions for cases of difficult sonic windows. Transplantation proceedings 2004;36:2896.

16. Sloan MA, Alexandrov AV, Tegeler $\mathrm{CH}$, et al. Assessment: transcranial Doppler ultrasonography: report of the Therapeutics and Technology Assessment Subcommittee of the American Academy of Neurology. Neurology 2004;62:1468.

17. Lampl Y, Gilad R, Eschel Y, et al. Diagnosing brain death using the transcranial Doppler with a transorbital approach. Archives of neurology 2002;59:58.

18. Soldatos T, Karakitsos D, Wachtel M, et al. The value of transcranial Doppler sonography with a transorbital approach in the confirmation of cerebral circulatory arrest. Transplantation proceedings 2010;42:1502.

19. Baumgartner RW. Transcranial color duplex sonography in cerebrovascular disease: a systematic review. Cerebrovascular diseases 2003;16:4.

20. Krejza J, Swiat M, Pawlak MA, et al. Suitability of temporal bone acoustic window: conventional TCD versus transcranial color-coded duplex sonography. Journal of neuroimaging : official journal of the American Society of Neuroimaging 2007;17:311. 
21. Poularas J, Karakitsos D, Kouraklis G, et al. Comparison between transcranial color Doppler ultrasonography and angiography in the confirmation of brain death. Transplantation proceedings 2006;38:1213.

22. Topcuoglu MA, Arsava EM. Transkranial renkli Doppler ultrasonografide "polis çakar lambası (flaşör) işareti": Beyin ölümü doğrulaması için az tanınan bir bulgu. Türk Beyin Damar Hast Derg 2014;20:36.

23. Bogdahn U, Becker G, Winkler J, et al. Transcranial color- coded real-time sonography in adults. Stroke; a journal of cerebral circulation 1990;21:1680.

24. Suzuki R, Koga M, Mori M, et al. Visibility of the lesser sphenoid wing is an important indicator for detecting the middle cerebral artery on transcranial color-coded sonography. Cerebrovascular diseases 2012;33:272.

25. McCarville MB. Comparison of duplex and nonduplex transcranial Doppler ultrasonography. Ultrasound quarterly 2008;24:167. 